\title{
ALIRAN-ALIRAN DALAM ILMU NEGARA MENURUT CALVINIS,HEGEL, KARL MARX, ROBERT OWEN, SAINT SIMON, FOURIER, DAN BAKUNIN
}

\author{
RAHMADENNY \\ rahmadenny1999@gmail.com \\ 2010003600151 \\ Universitas Ekasakti
}

\section{A. PENDAHULUAN}

Tentang Konsep Ilmu Negara, Ilmu Negara ini merupakan mata kuliah pengantar. Sebagai mata kuliah pengantar, maka pengetahuan yang diperoleh dari mata kuliah ini tidak mempunyai nilai-nilai yang praktis, tetapi mempunyai nilai yang teoretis, artinya dari pengetahuan mata kuliah Ilmu Negara tidak dapat menggunakan hasilnya secara langsung di dalam praktik. Materi ini terdiri dari 3 kegiatan belajar, yaitu Pengertian dan Objek Ilmu Negara, Hubungan antara Ilmu Negara dengan Ilmu Politik dan Ilmu Kenegaraan serta Aliranaliran Ilmu Negara.

Dalam susunan kurikulum fakultas Hukum aliran ilmu negara dimasukan sebagai salah satu mata pelajaran dalam tingkat persiapan seperti halnya pengantar ilmu hukum dan mata pelajaran lainya, tugas mata pelajaran tersebut sebagai pengantar terhadap mata pelajaran seperti hukum tinggi. Maka ilmu negara akan mengantar para mahasiswa untuk mempelajari hukum publik, khususnya hukum tata negara dan administrasi negara.

Secara umum setelah mempelajari beberapa materi ini dapat menjelaskan tentang konsep Ilmu Negara serta hubungan Ilmu Negara dengan Ilmu Politik dan Kenegaraan. Secara khusus Anda diharapkan dapat Menjelaskan pengertian Ilmu Negara dari pendapat beberapa ahli, Menjelaskan objek Ilmu Negara, Menjelaskan hubungan antara Ilmu Negara dengan Ilmu Politik dan Ilmu Kenegaraan, Menjelaskan aliran-aliran dalam Ilmu Negara 
Secara sistematis materi tentang aliran aliran ilmu negara ini dibagi dalam 3 Kegiatan Belajar, yaitu Kegiatan Belajar 1 dengan Pengertian Ilmu Negara dan Objek Ilmu Negara. Kegiatan belajar 2 Hubungan antara Ilmu Negara dengan Ilmu Politik dan Ilmu Kenegaraan dan Kegiatan Belajar 3 dengan Aliran-aliran dalam Ilmu Negara tentang pengertian Ilmu Negara dan Objek Ilmu Negara. Kelahiran dan kehadiran Ilmu Negara tidak dapat lepas dari jasa George Jellinek, seorang pakar hukum dari Jerman yang kemudian di kenal sebagai bapak Ilmu Negara. sehubungan dengan pendapat rengers hora siccama tersebut maka dapatlah disamakan perumpamaan yang pertama sebagai tugas ilmu negara yang tidak mementingkan teoritisnya ilmu negara sebagai ilmu pengetahuan dasar harus benar benar memberikan dasar yang bermanfaat dalam mempelajari serta menyelidi hukum tata negara.

Defenesi ilmu negara, ilmu negara dapat diartikan dengan ilmu pengetahuan yang menyelidiki asas-asas pokok dan pengertian pengertian pokok tentang negara dan hukum tata negara maka pertama-tama yang harus dijelaskan adalah arti dari pada ilmu pengetahuan yang merupakan hasil pemikiran yang objektif dan disusun secara sistematis. Ilmu pengetahuan ini hanya melukiskan tentang unsur-unsur negara, aspek-aspek negara, dan segala bahan yang menggambarkan suatu negara tertentu atau negara pada umumnya yang sering disebut dengan Statenkunde. Dari bahan yang diperoleh Statenkunde ini kemudian dicari persamaannya di bidang hukum guna menyusun perumusan-perumusan yang berlaku bagi semua bahan-bahan tersebut.

Dari uraian tersebut diatas, dengan jelas dapat diketahui perumusan yang kita berikan mengenai arti dari ilmu negara sebagai ilmu pengetahuan yang mempelajari pengertianpengertian dan asas-asas pokok tentang negara, hukum tata negara dan aliran-aliran ilmu negara. 


\section{B. PEMBAHASAN}

Pengertian Ilmu Negara Secara umum, ilmu negara dapat diartikan sebagai ilmu pengetahuan yang menyelidiki asas-asas pokok dan pengertian pokok tentang negara dan hukum tata negara. Sebagai ilmu pengetahuan, ilmu negara harus memenuhi 2 syarat pokok sebagai ilmu pengetahuan, yaitu :

- Syarat Objektif, bahwa kebenarannya harus dapat diterima umum.

- Syarat Sistematis, dimana pengertian-pengertian yang diperolehnya tidak boleh bercerai berai melainkan merupakan satu kesatuan yang erat.

Unsur-unsur ideal ilmu pengetahuan dapat bersumber pada akal pikiran manusia atau pada perasaannya. Jika suatu bangunan hukum itu bersumber pada akal pikiran maka disebut sebagai pengertian-pengertian hukum. Dan jika bangunan hukum itu bersumber pada perasaan maka hukum itu disebut sebagai asas-asas hukum. Demikian pula dalam ilmu negara, dikenal adanya asas-asas dan pengertian-pengertian mengenai Negara dan Hukum Tata Negara. Pengertian-pengertian dalam ilmu negara pada umumnya bersifat tetap, sedangkan asasnya seringkali berubah-ubah. Perubahanperubahan dalam asasnya disebabkan oleh pandangan hidup dan keduniaan dari masyarakat yang berbeda-beda.

Aliran Dalam Ilmu Negara. Aliran-aliran dalam Ilmu Negara, adalah pahampaham atau pendapat-pendapat yang pada suatu waktu dalam perkembangan sejarah manusia mempunyai pengaruh besar terhadap ketatanegaraan. Untuk menguraikan paham-paham dalam Ilmu Negara mesti dimulai dari paham yang paling kuno, yaitu paham jaman Yunani Kuno. Aliran-aliran dalam Ilmu Negara menurut pendapat para filsuf jaman Yunani Kuno : 


\section{Aliran Calvanis}

Paham dari aliran Calvinis mendasarkan ajarannya pada kedaulatan Tuhan dan mengembalikan semua kekuasaan kepada Tuhan, hanya saja aliran ini tidak mengakui gereja sebagai perantara dari Tuhan dan juga tidak mengakui kekuasaan dari Paus. Kekuasaan negara adalah langsung berdasarkan kekuasaan Tuhan. Menurut aliran Calvinis kekuasaan negara merupakan pemberian dari Tuhan yang dipegang oleh seorang raja. Kekuasaan negara menurut aliran ini dibatasi, bahwa negara tidak bisa campur tangan terhadap golongangolongan yang telah ada dalam masyarakat, seperti keluarga perusahaan, kesenian, dan lainlain. Asas yang terkenal pada aliran Calvinis adalah kedaulatannya di dalam lingkungannya sendiri, yang berarti bahwa mereka bebas dalam menyelenggarakan kepentingannya sendiri tanpa dicampuri oleh negara.

Aliran calvinis memiliki faham yang sama dengan golongan katolik, aliran ini mendasarkan ajarannya pada kedaulatan tuhan dan mengembalikan semua kekuasaan kepada tuhan, hanya bedanya dengan golongan katolik yaitu aliran ini tidak mengakui gereja sebagai perantara dari tuhan,dan juga tidak mengakui kekuasaan paus. Kekuasaan negara adalah secara tidak lansung didapat dari tuhan melalui manusia dengan budinya yang berasal dari tuhan, menurut golongan calvinis kekuasaan negara merupakan pemberian dari tuhan yang dipegang raja oleh karena itu negara yang menganut faham nya, pengumuman mengenai undang-undangnya senantiasa didahului dengan kalimat karunia tuhan, sama hal nya dengan katolik, golongan calvinis juga beranggapan negara tidak bisa ikut campur tangan terhadap golongan yang ada pada mahsyarakat seperti keluarga, perusahaan dan sebagainya. Asas nya yang terkenal adalah kedaulatannya didalam lingkungan sendiri yang berarti bahwa mereka bebas dalam menyelenggarakan kepentingannya sendiri tanpa dicampuri oleh negara. 


\section{Aliran Hegel}

Hegel terkenal dalam ilmu pengetahuan karena filsafatnya, namun didalam ajaran itu ia menyinggung tentang negara. Dalam filsafatnya untuk mencari kebenaran ia memiliki sebuah metode yang penting yang disebut dialektika yaitu suatu metode dengan mengemukakan thesis yang kemudian disangkal dengan antithesis. Hasil dari perlawanan ini diperoleh synthesis yang merupakan kesimpulan dialektesis dan tersusun dari kedua unsur yang berlawanan itu. Negara merupakan kesimpulan dari 2 unsur yang berlainan, keterangannya sebagai berikut: Manusia adalah warga dalam masyarakat dan dalam sifat perorangannya ia ingin mendahulukan kepentingannya sendiri sebagai tujuan utama. Kemudian individu-individu itu membentuk masyarakat yang belum teratur karena belum ada badan yang mengatur kedua unsurtersebut yang kemudian dinamakan negara sebagai perwujudannya. Karena negara merupakan perwujudan cita-cita manusia yang mutlak maka negara adalah satu-satunya badan yang paling sempurna dimasyarakat yang paling sempurna dan harus dijunjung tinggi.

Ajaran Hegel yang mutlak tersebut disebut sebagai absolut idealisme. Akibat ajaran ini timbullah anggapan bahwa negara harus didewakan dan menyebabkan faham tentang kedaulatan negara yang beranggapan bahwa semua kekuasaan bersumber pada negara. Ajaran ini mempengaruhi aliran Deutsche Publizisten Schule yang juga mendukung faham kedaulatan negara jerman dengan Karl Marx mempergunakan metode dialektika.

\section{Karl Marx}

Karl Marx dalam bukunya yang berjudul "Das Komunistische Manifest" tahun 1848, menyebutkan bahwa : 
- negara akan tetap ada sebagai suatu organisasi akibat dari suatu penjelmaaan dari sejarah dan sebagai hasil dari kehidupan manusia itu sendiri. Negara sebagai alat kekuasaan untuk menindas dan menguasai golongan lain akan lenyap dan berubah menjadi masyarakat yang tidak bernegara dan tidak berkelas.

Ajaran Karl Marx ini disebut sosialisme ilmiah, suatu sosialisme yang telah memperoleh penilaian sebagai ilmu pengetahuan karena ajarannya mengandung kebenaran bagi kaum komunis. Pendapat Marx selanjutnya adalah suatu keharusan dari perkembangan sejarah manusia bahwa masyarakat akan menuju sosialisme yang dipimpin oleh diktator proletar.

Pada mulanya Karl Marx setuju dengan pendapat Hegel bahwa negara itu merupakan perwujudan dari Stittichkeit und Vermunt namun pada tahun 1844 ia meninggalkan ajaran tersebut. Marx tidak membenarkan pendapat Hegel yang melihat negara dari sudut alam cita-cita tetapi ia melihat hubungan masyarakat sebagai suatu kenyataan. Menurutnya dasar menentukan negara ialah negara kelas. Ajarannya tentang ilmu negara terdapat pada bukunya yang berjudul Das Komunistische Manifest pada tahun 1848. Menurut Marx negara akan tetap ada sebagai organisasi akibat dari suatu penjelmaan dari sejarah dan sebagai hasil dari kehidupan manusia itu sendiri jika kemajuana-kemajuan dalam prosese produksi dan pembagiankerja terdapat dan selama hak milik memegang peranan yang penting. Ajaran Marx disebut sosialisme ilmiah yaitu suatu sosialisme yang telah memperoleh penilaian sebagai ilmu pengetahuan karena ajarannya mengandung kebenaran bagi kaum komunis. Pendapat Marx selanjutnya "adalah suatu keharusan dari perkembangan sejarah manusia bahwa masyarakat akan menuju kearah sosialisme yang dipimpin oleh diktator proletar. 


\section{Robert Owen (1771 - 1858) di Inggris}

Seorang pengusaha dan menganggap bahwa tenaga produktif manusia pada waktu itu tidak dipergunakan dengan sebaik-baiknya sehingga tidak menghasilkan kemakmuran, juga segimoral dari masyarakat itu tidak dibina dengan baik sehingga akibatnya mendatangkan kemiskinan dan dosa. Pemikiran Owen lebih moderat dalam artian tidak terlalu mengedepankan pertentangan kelas dan perjuangan kekerasan tetapi lebih mengedepankan kerjasama daripada kompetisi. Owen lebih mempercayai bahwa yang harus berperan besar adalah komunitas kolektif kecil. Pemikirannya tentang sosialisme dia tuangkan dalam buku yang berjudul "A New View of Society, an Essay on the Formation of Human Character" (1813). Dalam bukunya tersebut, ia menyatakan bahwa lingkungan social berpengaruh pada pembentukan karakter manusia. Ia berusaha mencari caranya dengan meningkatkan kesejahteraan pekerjanya. Dalam bukunya tersebut juga mempersoalkan tentang pendidikan, dimana kejahatan-kejahatan dalam masyarakat disebabkan keadaan dan bukan oleh kejatuhan moral manusia sehingga pendidikan dalam suatu lingkungan yang baru akan dapat menghasilkan manusia-manusia rasional yang mempunyai kebiasaan teratur, sungguh-sungguh, sabar dan rajin.

Robert Owen merupakan tokoh pertama yang mengembangkan benih-benih pemikiran socialisme Inggris. Hubungan kekeluargaan di antara sosialisme dan kapitalisme dapat terlihat dari kenyataan bahwa social modern yang pertama adalah seorang kapitalis kaya dan berhasil. Sebagai seorang kapitalis yang "self-made" ia telah berhasil mengumpulkan harta kekayaan menjelang umur 40 tahun. Ia adalah seorang pemikir yang ulet yang mempunyai pertimbangan praktis._Owen juga lebih mudah dapat menghadapi satu ujian pengalaman yang oleh kaum konservatif sering dikatakan perlu dan penting . 


\section{Saint Simon $(1760$ - 1825) di Prancis}

Seorang bangsawan di Perancis dan merasa tidak puas dengan hasil Revolusi Prancis, karena hasilnya dinikmati oleh golongan bangsawan saja yang mempunyai ciri golongan kapitalis. Dalam pendapatnya yang unik, ia membedakan dua golongan yang bekerja dan golongan yang malas. Golongan yang malas akan menderita kekalahan karena kehilangan kewibawaan sedangkan golongan orang yang tidak berada, tidak mampu memimpin masyarakat baik dalam kerohaniannya maupun dalam bidang politik. Menurutnya politik ditentukan oleh perekonomian rakyatnya baik dalam pengusahaan administrasinya maupun dalam produksinya, sehingga kekuasaan politik aras golongan lainya harus dirubah dan akhirnya negara akan hilang.

\section{Fourier}

Seorang kritikus dan seorang satiris. Menurut pendapatnya didalam masyarakat kapitalis terdapat penumpukan modal yang besar, yang dipeloh dari penderitaan dan kemiskinan dari pihak lain. Kemiskinan akan membawa bencana yang besar terhadap moral manusia sehingga hilanglah kepribadian dari manusia itu. Selanjutnya ia brpendapat dengan makin meningkatnya produksi sebagai hasil ciptaan manusia dapat dipenuhi sehingga keadilan sosial bisa dicapai.Kembali kepada ajaran Marx.

Marx dalam menerangkan perubahan sosial (masyrakat) mempergunakan metode dialektika dari Hegel dengan memutar balikkan teori Hegel yaitu kalauHegel berpendapat bahwa cita-cita manusia yang menentukan kenyataan, maka Marx justru sebaliknya kenyataanlah yang menentukan kesadaran manusia. Menurutnya susunan masyarakattimbul terutama ditentukan oleh kehidupan masyarakat itu sendiri. 


\section{Bakunin}

Dalam waktu yang kira-kira sama muncul suatu pendapat yang berbeda dengan faham Marx walaupun pada titik penghabisannya adalah sama. Bakunin yang hidup pada tahun 1814 - 1876 memiliki faham lebih radikal dari Marx. Ia menghendaki hilangnya negara dimuka bumi karena negara merupakan suatu penyakit bagi masyarakat. Karena adanya negara maka timbullah penindasan dan senantiasa merupakan alat bagi yang berkuasa untuk menindas golongan lain yang dikuasainya. Karena itu negara harus dilenyapkan dari muka bumi dan sebagai gantinya dibentuk perserikatan-perserikatan individu yang bebas dari segala macam tekanan. Apakah akibat dari faham Bakunin ini? Akibatnya ialah akan timbul kekacauan-kekacauan di dalam masyarakat yang mempunyai negara. Kalau dilihat dari sudut tata tertib dimana negara sangat diperlukan, pendapat Bakunin ini justru menghendaki kekuasaan diatasnya dan disebut anarkhisme. Faham ini tidak banyak pengikutnya dan buktinya hingga sekarang masyarakat masih mengakui perlu adanya negara. Faham ini juga tidak mengikuti sejarah manusia dan ilmu negara ia tidak mendapat tempat yang subur.

\section{PENUTUP}

Kedudukan negara di dalam masyarakat berpangkal pada manusia sebagai makhluk masyarakat (animal social) disamping manusia sebagai makhluk politik (animal politicum). Selanjutnya diterangkan bahwa masyarakat yang memiliki kewajiban adalah manusia yang menurut kodratnya dianugrahi Tuhan. Tugas negara adalah menyempurnakan tertib hukum kodrat. Pada waktu itu manusia mencari hukum yang lebih sempurna dari hukum positif, yang kemudian disebut hukum alam yang sifatnya abadi dan tidak berubah-ubah karena pengaruh 
waktu dan tempat. Hukum alam ini adalah hukum yang timbul dari kodrat manusia sebagai makhluk ciptaan Tuhan yang berbudi luhur. Asas dari hukumalam ini disebut sebagai asas primer yang merupakan peraturan dasar dan dapat diisi serta ditambah dengan hukum positif sesuai dengan kebutuhan masyrakatnya. Dan hukum positif tersebut tidak boleh bertentangan dengan asas hukum alam yang timbul karena budi manusia tersebut. Selain menyempurnakan tertib hukum, ia juga harus menyelenggarakan kesejahteraan umum untuk warganegaranya. Ilmu Negara menurut faham Katolik adalah sebagian dari ajaran yang bersifat solidaritas dan sebagai lawan dari faham liberal dan sosialisme.Negara harus membahaskan diri untuk mencampuri urusan orang perseorangan, keluarga dan masyarakat dengan hukum-hukum lainnya karena mereka lebih mengenal akan kepentinganmereka sendiri dan lebih tahu bagaimana caranya untuk menyelenggarakan kepentingan tersebutwalaupun didalam masalah ekonomi, kebudayaan dan sosial. Namun apabila kepentingan umumdirugikan, maka negara harus ikut campur tangan. Asas ini disebut asas subsidair. Dengan demikian jelas bahwa tugas negara adalah terbatas dan faham ini adalah bertentangan dengan faham otoriter.

\section{DAFTAR PUSTAKA}

Darmini Roza dan Laurensius Arliman S Peran Pemerintah Daerah Di Dalam Melindungi Hak Anak Di Indonesia, Masalah-Masalah Hukum, Volume 47, Nomor 1, 2018.

Laurensius Arliman S, Komnas HAM dan Perlindungan Anak Pelaku Tindak Pidana, Deepublish, Yogyakarta, 2015.

Laurensius Arliman S, Penguatan Perlindungan Anak Dari Tindakan Human Trafficking Di Daerah Perbatasan Indonesia, Jurnal Selat, Volume 4, Nomor 1, 2016.

Laurensius Arliman S, Problematika Dan Solusi Pemenuhan Perlindungan Hak Anak Sebagai Tersangka Tindak Pidana Di Satlantas Polresta Pariaman, Justicia Islamica, Volume 13, Nomor 2, 2016. 
Laurensius Arliman S, Pelaksanaan Perlindungan Anak Yang Tereksploitasi Secara Ekonomi Oleh Pemerintah Kota Padang, Veritas et Justitia, Volume 2, Nomor 1, 2016.

Laurensius Arliman S, Kedudukan Ketetapan MPR Dalam Hierarki Peraturan PerundangUndangan Di Indonesia, Lex Jurnalica, Volume 13, Nomor 3, 2016.

Laurensius Arliman S, Komnas Perempuan Sebagai State Auxialiary Bodies Dalam Penegakan Ham Perempuan Indonesia, Justicia Islamica, Volume 14, Nomor 2, 2017.

Laurensius Arliman S, Peranan Pers Untuk Mewujudkan Perlindungan Anak Berkelanjutan Di Indonesia, Jurnal Ilmu Hukum Tambun Bungai, Volume 2, Nomor 2, 2017.

Laurensius Arliman S, Mewujudkan Penegakan Hukum Yang Baik Untuk Mewujudkan Indonesia Sebagai Negara Hukum, Jurnal Hukum Doctrinal, Volume 2, Nomor 2, 2017.

Laurensius Arliman S, Participation Non-Governmental Organization In Protecting Child Rights In The Area Of Social Conflict, The 1st Ushuluddin and Islamic Thought International Conference (Usicon), Volume 1, 2017.

Laurensius Arliman S, Partisipasi Masyarakat Dalam Pembentukan Perundang-Undangan Untuk Mewujudkan Negara Kesejahteraan Indonesia, Jurnal Politik Pemerintahan Dharma Praja, Volume 10, Nomor 1, 2017, https://doi.org/10.33701/jppdp.v10i1.379.

Laurensius Arliman S, Peran Komisi Perlindungan Anak Indonesia Untuk Mewujudkan Perlindungan Anak, Jurnal Respublica Volume 17, Nomor 2, 2018.

Laurensius Arliman S, Menjerat Pelaku Penyuruh Pengrusakan Barang Milik Orang Lain Dengan Mempertimbangkan Asas Fungsi Sosial, Jurnal Gagasan Hukum, Volume 1, Nomor 1, 2019.

Laurensius Arliman S, Ilmu Perundang-Undangan Yang Baik Untuk Negara Indonesia, Deepublish, Yogyakarta, 2019.

Laurensius Arliman S, Isdal Veri, Gustiwarni, Elfitrayenti, Ade Sakurawati, Yasri, Pengaruh Karakteristik Individu, Perlindungan Hak Perempuan Terhadap Kualitas Pelayanan Komnas Perempuan Dengan Kompetensi Sumber Daya Manusia Sebagai Variabel Mediasi, Jurnal Menara Ekonomi: Penelitian dan Kajian Ilmiah Bidang Ekonomi, Volume 6, Nomor 2, 2020.

Laurensius Arliman S, Pendidikan Kewarganegaraan, Deepublish, Yogyakarta, 2020.

Laurensius Arliman S, Makna Keuangan Negara Dalam Pasal Pasal 23 E Undang-Undang Dasar 1945, Jurnal Lex Librum, Volume 6, Nomor 2 Juni 2020, http://dx.doi.org/10.46839/1ljih.v6i2.151. 
Laurensius Arliman S, Kedudukan Lembaga Negara Independen Di Indonesia Untuk Mencapai Tujuan Negara Hukum, Kertha Semaya Journal Ilmu Hukum, Volume 8, Nomor 7, 2020.

Laurensius Arliman S, Pelaksanaan Assesment Oleh Polres Kepulauan Mentawai Sebagai Bentuk Pelaksanaan Rehabilitasi Bagi Pecandu Dan Korban Penyalahgunaan Narkotika, Jurnal Muhakkamah, Volume 5, Nomor 1, 2020.

Laurensius Arliman S, Aswandi Aswandi, Firgi Nurdiansyah, Laxmy Defilah, Nova Sari Yudistia, Ni Putu Eka, Viona Putri, Zakia Zakia, Ernita Arief, Prinsip, Mekanisme Dan Bentuk Pelayanan Informasi Kepada Publik Oleh Direktorat Jenderal Pajak, Volume 17, No Nomor, 2020.

Larensius Arliman S, Koordinasi PT. Pegadaian (Persero) Dengan Direktorat Reserse Narkoba Polda Sumbar Dalam Penimbangan Barang Bukti Penyalahgunaan Narkotika, UIR Law Review, Volume 4, Nomor 2, 2020, https://doi.org/10.25299/uirlrev.2020.vol4(1).3779.

Laurensius Arliman S, Tantangan Pendidikan Kewarganegaraan Pada Revolusi 4.0, Ensiklopedia Sosial Review, Volume 2, Nomor 3, 2020.

Muhammad Afif dan Laurensius Arliman S, Protection Of Children's Rights Of The Islamic And Constitutional Law Perspective Of The Republic Of Indonesia, Proceeding: Internasional Conference On Humanity, Law And Sharia (Ichlash), Volume 1, Nomor 2, 2020.

Otong Rosadi danLaurensius Arliman S, Urgensi Pengaturan Badan Pembinaan Idelogi Pancasila Berdasarkan Undang-Undang Sebagai State Auxiliary Bodies yang Merawat Pancasila dalam Perspektif Hak Asasi Manusia, Prosiding Konferensi Nasional Hak Asasi Manusia, Kebudayaan dan Tujuan Pembangunan Berkelanjutan Indonesia pada Masa Pandemi Covid-19: Tantangan untuk Keilmuan Hukum dan Sosial Volume 1, Universitas Pancasila, Jakarta, 2020. 